ROCZNIKI HISTORYCZNE

Rocznik LXXXII - 2016

PAWEŁ STRÓŻYK (Uniwersytet im. Adama Mickiewicza, Poznań)

\title{
Herby na gotyckiej chrzcielnicy z katedry w Poznaniu
}

Zarys treści: Artykuł omawia ujawnione w 2016 r., barwne herby rycerskie, fragmentarycznie zachowane na gotyckiej, metalowej chrzcielnicy z katedry w Poznaniu. Malowane herby łączyć należy z biskupem poznańskim Andrzejem z Bnina (ok. 1396/1397-1479), cały zaś obiekt datować na lata 1435-1447, z ostrożnym uściśleniem na lata 1439-1447.

Content outline: The paper discusses the colour coats-of-arms, fragments of which were found in 2016 on the gothic metal baptismal font in the Poznań Cathedral. The painted arms must be related to Andrzej of Bnin, bishop of Poznan (circa 1396/1397-1479), while the whole object may be dated to the years 1435-1447, possibly narrowing the time to $1439-1447$.

Słowa kluczowe: heraldyka, herby rycerskie, polichromia gotycka, gotycka chrzcielnica metalowa, katedra poznańska, biskup poznański Andrzej z Bnina

Keywords: heraldry, knightly coats-of-arms, gothic polychromy, gothic matal baptismal font, Poznań Cathedral, bishop of Poznań, Andrzej of Bnin

W katedrze poznańskiej pw. Świętych Apostołów Piotra i Pawła znajduje się obiekt zwykle niedostrzegany przez zwiedzających, skupionych głównie na detalach architektonicznych, obrazach czy spektakularnych obiektach sepulkralnych (spiżowych płytach nagrobnych i kamiennych nagrobkach). Jest to metalowa, średniowieczna chrzcielnica, która będzie przedmiotem poniższych uwag. W związku z przygotowywanymi w katedrze obchodami 1050. rocznicy chrztu księcia Mieszka, konserwatorzy z pracowni Muzeum Archidiecezjalnego w Poznaniu otrzymali w kwietniu 2016 r. zlecenie oczyszczenia obiektu, aby ten godnie prezentował się w trakcie przygotowywanych uroczystości. Już w czasie przenoszenia chrzcielnicy z katedry do siedziby Muzeum dostrzeżono w świetle dziennym resztki polichromii z fragmentami herbów, które uwydatniły się po zabiegach czyszcząco-konserwujących. Nie jest to może klasyczne odkrycie konserwatorskie, ale gdyby nie otrzymane zlecenie, kto wie, jak długo jeszcze przechodzilibyśmy obok tego obiektu (stojącego notabene w miejscu niedoświetlonym), nie dostrzegając na nim resztek dekoracji heraldycznej.

Chrzcielnica jest wzmiankowana w literaturze przedmiotu i katedralnych przewodnikach, ale bez informacji o zachowanych na niej herbach ${ }^{1}$. Wspomniał ją lakonicznie Julius Kohte ${ }^{2}$, odnotowali wydawcy Katalogu zabytków sztuki w Polsce, Eugeniusz

${ }^{1}$ S. N a w r o c k i, Przewodnik po katedrze poznańskiej, Poznań 1930, s. 24; M. P a l u s z k i e w i c z, Katedra poznańska i jej zabytki, Poznań 1938, s. 26.

2 J. K o h t e, Die Kunstdenkmäler des Stadtkreises Posen (Verzeichnis der Kunstdenkmäler der Provinz Posen, t. II), Berlin 1896, s. 15. 
Linette i Zofia Kurzawa ${ }^{3}$, datując ją na pierwszą połowę XV w., ale więcej uwagi poświęcił jej tylko ks. Józef Nowacki ${ }^{4}$. Zestawił on wszelkie wzmianki na temat chrzcielnicy katedralnej, do jakich dotarł w trakcie swoich szerokich kwerend archiwalnych. Wiele uwagi poświęcił przy tym miejscu, w którym znajdował się interesujący nas obiekt. Najstarsza znana mu wzmianka o chrzcielnicy zawarta jest w datacji aktu z niedzieli 30 IV 1447 r.: in corpore ecclesiae Posnaniensis circa fontem baptismatis. W nawie głównej chrzcielnica stała jeszcze podczas wizytacji przeprowadzonej w 1622 r. W dekrecie wizytacyjnym z 1660 r. biskup Wojciech Tolibowski polecił umieścić ją w kaplicy Szołdrdskich. W kaplicy mansjonarskiej (obecnie na tym miejscu Złota Kaplica) chrzcielnica wzmiankowana jest w wizytacji biskupa Jana Joachima Tarły z 1728 r. Podczas wizytacji biskupa Stanisława Hozjusza w 1737 r. stała w dawnym miejscu in medio ecclesiae prope sepulchrum regis Boleslai Chrabry. Przed 1781 r. znajdowała się w kaplicy Świętej Trójcy, a w XIX w. - w kaplicy św. Jana Kantego, gdzie była także w czasach ks. J. Nowackiego.

W wizytacji biskupa Macieja Łubieńskiego z 1628 r. określona została jako fons baptismalis cupreus, czyli chrzcielnica miedziana. Najprawdopodobniej wskutek zawalenia się sklepienia po pożarze w $1622 \mathrm{r}$. została uszkodzona jej podstawa. Obiekt został chyba rychło naprawiony, nie mamy bowiem wzmianek o nowej chrzcielnicy, a biskup Wojciech Tolibowski w 1660 r., zapowiadając gotowość sprawienia nowej chrzcielnicy i otoczenia jej kratą, pośrednio potwierdzał istnienie starego obiektu. Prawdopodobnie jednak nie doszło do zrealizowania biskupiej obietnicy. Chrzcielnicę wspominają wizytacje katedralne z lat 1728 i 1737, a wizytacja z 1781 r. nadmienia, że była ona z miedzi - co pozwala przyjąć, że chodzi wciąż o ten sam artefakt, który wymieniono w $1628 \mathrm{r}$. Źródła wspominają też o reperacjach chrzcielnicy - w $1745 \mathrm{r}$. (naprawy dokonał kotlarz Roman, co też pośrednio wskazuje na metal, jako tworzywo obiektu) oraz na przełomie lat 1816 i 1817 (i tu wspomniano kotlarza, bez podania jego imienia).

Ks. J. Nowacki słusznie przyjął, że wszystkie zebrane wzmianki źródłowe, od 1447 r. począwszy, dotyczą jednego i tego samego obiektu - chrzcielnicy miedzianej (wprost wzmiankowanej jako taka w latach 1628 i 1781, pośrednio zaś w 1745 i 1816/1817), która dotrwała do naszych czasów. Mimo że w 1622 r. chrzcielnica została uszkodzona, nadal pozostała w użyciu. „Prawdopodobnie dokonano naprawy w ten sposób, że odcięto najniższą kondygnację jej podstawy aż do połowy wypukłości, którą rozcięto i spłaszczono tworząc z niej nową podstawę" ${ }^{\text {. Ważna dla naszych }}$ dalszych rozważań jest pierwsza wzmianka o chrzcielnicy, wyznaczająca terminus ante quem jej powstania na $30 \mathrm{IV} 1447 \mathrm{r}$.

Gotycka, metalowa chrzcielnica, na której zachowały się resztki barwnej polichromii, stała w ostatnich latach w kaplicy Matki Boskiej i św. św. Aniołów (tzw. kaplicy Szołdrskich). Obiekt o wysokości $155 \mathrm{~cm}$ i średnicy $76 \mathrm{~cm}$, o kształcie kielicha zdobionego wyciętymi z blachy drobnymi fryzami z motywem lilii, wieńczy wysoka,

${ }^{3}$ Katalog zabytków sztuki w Polsce, seria nowa, t. VII, cz. 1, red. E. Linette, Z. Kurzawa, Warszawa 1983, s. 41, fot. 126.

${ }^{4}$ J. N o w a c k i, Dzieje archidiecezji poznańskiej, t. I, Poznań 1959, s. 458-460, fot. 77. Za nim przywołujemy wzmianki dotyczące chrzcielnicy.

5 Tamże, s. 459. 
lejkowata pokrywa - jak to ujął obrazowo ks. J. Nowacki - „upływająca w smukły, ośmiokątny hełm wieżowy" (naprawiany), świadczą jego zachwiane proporcje (fot. 1 i 1a). Resztki pierwotnej polichromii zachowały się na pokrywie. Są to motywy florystyczne i interesujące nas, fragmentarycznie zachowane elementy heraldyczne. Mowa tu o czterech malowanych tarczach herbowych, umieszczonych w czterech $\mathrm{z}$ ośmiu zamkniętych profilowo pól pokrywy chrzcielnicy, w dolnych ich częściach, poniżej dekoracyjnego fryzu wyciętego w blasze. Herby zostały namalowane w późnogotyckich tarczach (wysokości ok. 13-14,5 cm, a szerokości 12-13 cm) z wyraźnie widocznymi, żółtymi (heraldycznie: złotymi) bordiurami, których bieg wyznaczały linie odmalowane czarną farbą. Bordiury występowały w XV w. w polskiej heraldyce, miały jednak zwykle dekoracyjny charakter, tworząc szeroki kontur tarczy herbowej ${ }^{7}$ (fot. 3). Poszczególne tarcze namalowane na chrzcielnicy różnią się nieznacznie kształtem i wymiarami, a ich czarne linie, wyznaczające kontury, nie są idealnie poprowadzone, co świadczy, że malowane były bez użycia szablonu. Boczne krawędzie tarcz schodzą od czoła ku dołowi, równolegle lub po lekko dostrzegalnym łuku, następnie zaś przechodzą w łuki, które ostro zamykają ich podstawy, co doskonale widać na jednej z zachowanych tarcz (fot. 2). Tarcze o takim kształcie występują na ziemiach polskich na obiektach datowanych od lat dwudziestych XV w. ${ }^{8}$

Opis herbów rozpoczniemy od tych lepiej zachowanych, zaznaczając przy tym, że nie dostrzegamy żadnych wizualnych wskazówek co do tego, który ze znaków należałoby uznać za otwierający i kluczowy dla całego przedstawionego zespołu. W pierwszym herbie, w polu czerwonym, zachowanym na znacznej powierzchni tarczy, widoczny jest poprowadzony czarną kreską zarys kolistego godła, w środku pustego, jak świadczą zachowane w tym miejscu pozostałości czerwonej barwy pola tarczy. Zdecydowanie lepiej widoczny jest kształt górnej części godła (fot. 4). Farba na powierzchni godła została wydrapana, ale jej resztki zachowane tuż przy czarnej linii separującej barwę godła od barwy pola upewniają nas, że godło było odmalowane białą (heraldycznie: srebrną) farbą (fot. 5). Porównanie kształtu i barw zachowanych elementów ze znanymi herbami średniowiecznego rycerstwa polskiego pozwala przyjąć, że mamy tu do czynienia $\mathrm{z}$ herbem Nałęcz (w polu czerwonym pomłość srebrna), w wersji ze srebrnym, a nie złotym, godłem?.

6 Tamże.

${ }^{7}$ P. Mrozow s k i, O sztuce i stylizacji heraldycznej w Polsce XIV-XV wieku, Rocznik Polskiego Towarzystwa Heraldycznego, nowa seria 1 (12), 1993, s. 85-86, fot. 9, tabl. II/5, VIII/3. Autor podkreślił, że „,bordiura polska nie niosła tymczasem konkretnych znaczeń, jak francuska bordure. Była dekoracją, początkowo tylko formą silnie rozbudowanego konturu”. Być może w tym drugim kontekście postrzegać należy wariant herbu Dołęga, uwzględniony przez J. S z y mań s k i e g o, Herbarz średniowiecznego rycerstwa polskiego, Warszawa 1993, s. 114. Zob. także F. P i e k o s i ń s k i, Heraldyka polska wieków średnich, Kraków 1899, s. 372.

${ }^{8}$ P. Mrozow s ki, O sztuce, s. 83 i tabl. VIII/3-4.

9 J. S z y mán s k i, Herbarz, s. 192-195. Nie zostały tam uwzględnione nieznane wówczas barwne herby z poznańskiej chrzcielnicy (podobnie jak herby $\mathrm{z}$ chrzcielnicy $\mathrm{w}$ katedrze gnieźnieńskiej - zob. niżej, przyp. 16). W niniejszym artykule stosuję nazwy herbów rycerskich według nomenklatury przyjętej przez J. Szymańskiego. 
Pole drugiego herbu, położonego naprzeciwlegle w stosunku do Nałęcza, także jest czerwone. Farba o tym kolorze pokrywa powierzchnię w górnej części tarczy (o kształcie dwóch trójkątów), oraz - fragmentarycznie - w dole tarczy i po jej bokach. Widoczny jest także zarys godła herbowego, oddany czarną kreską. Nie ma wątpliwości, że w tarczy przedstawiono łękawicę (fot. 6). Dwa polskie herby rycerskie miały taki element, rozmieszczony centralnie na powierzchni całej tarczy - Awdaniec i Syrokomla ${ }^{10}$. Ten drugi herb możemy wykluczyć, gdyż środkowy element górnej partii godła niemal styka się z linią wyznaczającą pole tarczy herbowej, nie ma zatem możliwości, aby pierwotnie znajdował się tam zaćwieczony krzyżyk kawalerski (fot. 7). Szczątkowo zachowały się też resztki białej farby (heraldycznie: srebrnej), pozwalające na określenie barwy godła (fot. 8). W drugiej tarczy przedstawiono zatem herb Awdaniec (w polu czerwonym łękawica srebrna).

Pole trzeciego herbu także jest czerwone, o czym przekonuje nas dość dobrze zachowana polichromia górnej części tarczy (do ok. ${ }^{1 / 3}$ jej wysokości) (fot. 9). Dolna część malunku jest niemal całkowicie zatarta. Wydaje się, że ubytki farby w górnym pasie tarczy, symetryczne co do położenia i kształtu, mogą wskazywać na to, że pierwotnie widniały tam jakieś fragmenty usuniętego godła herbowego. W kształt ubytków zachowanego fragmentu polichromii wpisują się godła dwóch herbów: Łodzia i Połkozic ${ }^{11}$. W pierwszym przypadku ubytki czerwonej farby w górnej części pola odpowiadałyby skrajnym, zadartym częściom łodzi, w drugim zaś - uszom widniejącej w godle oślej głowy. Możemy więc przyjąć wariantywnie, że na chrzcielnicy przedstawiono albo herb Łodzia (w polu czerwonym łódź złota), albo Półkozic (w polu czerwonym głowa osła czarna lub srebrna).

Kolejne i ostatnie wyobrażenie heraldyczne stanowi de facto jedynie kontur tarczy herbowej, w polu której zarysowuje się fragment godła o gwiaździście ułożonych elementach (fot. 10). W górnej, heraldycznie lewej części tarczy widać czarną linię, biegnącą od środka tarczy ku jej narożnikowi (fot.11). Ważne są także trzy czarne, łukowate linie widoczne u dołu tarczy (heraldycznie po prawej stronie), z których dwie, biegnąc równolegle po łuku, tworzą zarys tarczy z bordiurą, jedna zaś tworzy kontur dolnej części godła herbowego (fot. 12). Ta łukowata linia nie ma jednak przebiegu równoległego do zarysu tarczy (w górnym zachowanym fragmencie zbliża się ona do wewnętrznej linii tarczy), zatem w godle musiał pierwotnie widnieć element łukowaty dołem, ale różny od koła, połutoczenicy albo podkowy na opak. Możemy dlatego wykluczyć takie herby, jak: Becz, Bielina [I], Chorąbała, Dąbrowa [II], Jastrzębiec, Kuczaba, Lubcza, Łada, Mądrostki, Nowina wraz z jego ujęciem wariantywnym, Osoryja, Ratuł oraz jeden z herbów o nieznanej nazwie ${ }^{12}$. Wydaje się więc, że przebieg zachowanych w polu tarczy linii konturowych (łukowata linia u dołu tarczy i prosta linia biegnącą ku jej narożnikowi) najlepiej odpowiada elementom

10 Tamże, s. 74-76, 265-266.

11 Tamże, s. 227-229; 186-187.

12 Tamże, s. 77-78, 82-83, 97-98, 106-107, 138-141, 167-168, 179-180, 184, 187-188, 200-201, 212-214, 248, 307. Herb określony przez tego autora jako NN (tamże, s. 307), okazał się być Nowiną o wariantywnym rysunku godła. Identyfikacji tej dokonał B. Ś 1 i w iń s k i, Zagadkowy herb z kościoła w Bolechowicach koło Krakowa, Rocznik Polskiego Towarzystwa Heraldycznego, nowa seria 2 (13), 1995, s. 201-204. 
godła z herbu Leliwa, co zdają się też potwierdzać zachowane resztki niebieskiej farby w górnej, heraldycznie prawej części tarczy, wskazującej na barwę pola (fot. $13)^{13}$. Wykluczamy przy tym herby: Bielina [II], Drzewica, Prus [III], Sas, Szeliga i Trzaska ${ }^{14}$. Możemy zatem przyjąć, że w kolejnej tarczy przedstawiono herb Leliwa (w polu błękitnym pod gwiazdą złotą takiż księżyc). Godło było zapewne oddane żółtą farbą (heraldycznie: złotą), na co wskazuje kolor pola tarczy. Znane są nam też inne średniowieczne wersje barwne tego herbu, ale w wariancie o niebieskim polu tarczy, na co wskazują znane źródła, zawsze umieszczano złote godło (zarówno gwiazdę, jak księżyc). Dodajmy jeszcze, że heraldyczna gwiazda musiała mieć w tym przypadku długie i smukłe promienie ${ }^{15}$.

Punktem odniesienia dla naszego obiektu - przynajmniej na tym etapie badań musi pozostać podobna metalowa chrzcielnica, znajdująca się w katedrze w Gnieźnie. Heraldyka i epigrafika gnieźnieńskiego obiektu były już przedmiotem studiów ${ }^{16}$. Inskrypcja zachowana w złym stanie, ale wciąż możliwa do odczytania, wskazuje, że chrzcielnica ta pochodzi z 1448 r. Jest to zatem obiekt fundowany później niż ten z katedry w Poznaniu, przy założeniu, że cytowana wzmianka z 1447 r. dotyczy zachowanej do dziś chrzcielnicy. Herby znajdujące się na gnieźnieńskiej chrzcielnicy namalowano na jej czaszy, w dwóch grupach po trzy znaki. Choć mocno dziś zatarte, są jednak nieco lepiej widoczne niż te z obiektu poznańskiego. Analizując zespół herbów w Gniezna, przyjąłem ich następującą identyfikację: w pierwszej grupie Zaręba (w środku), Pirzchała (?) (heraldycznie z prawej) oraz Jelita (z lewej); w drugiej grupie, analogicznie - Jastrzębiec, Odrowąż (lub Ogon) oraz Kopacz. Pierwsza grupa herbów odnosi się najprawdopodobniej do osoby fundatora chrzcielnicy - Jana z Brzostkowa herbu Zaręba kantora gnieźnieńskiego, zasiadającego w kapitule od 1411 r. - i jego nieznanych bliżej przodków: matki oraz babki ojczystej lub macierzystej. Znane jest tylko imię ojca Jana z Brzostkowa (Arkembold), nic natomiast nie wiemy o matce ani babce. Możemy tak interpretować herby w pierwszej grupie, ponieważ w latach 1411-1448 nie zasiadali w kapitule przedstawiciele rodzin pieczętujących się Pirzchałą (jeśli to z tym herbem mamy do czynienia) i Jelitami. Druga grupa znaków przynosi prawdopodobnie wizerunki herbów wpływowych osób zasiadających w kapitule gnieźnieńskiej, bliżej związanych z Janem z Brzostkowa - dwóch prałatów: prepozyta Przedwoja z Grądów herbu Kopacz (ale może także kanonika Jana syna Chwała z Grądów), kanclerza Jana z Koziebród herbu Jastrzębiec (ale może także kanonika Wojciecha Rytwiańskiego) oraz kanonika Jana ze Sprowy herbu Odrowąż (późniejszego arcybiskupa gnieźnieńskiego).

13 J. S z y m a ń s k i, Herbarz, s. 173-176.

14 Tamże, s. 83-84, 119-120, 242, 256-257, 268.

15 Taki wysmukły kształt gwiazdy w herbie Leliwa spotykamy np. na płycie Rafała z Tarnowa z Przeworska (ok. 1441), a także na plakiecie z nagrobka Grotowiców ze Słupczy (2 połowa XV w.), zob. P. Mrozow sk i, Polskie nagrobki gotyckie, Warszawa 1994, il. $104,111$.

${ }^{16}$ P. S tró ży k, Barwne herby na średniowiecznej chrzcielnicy z katedry w Gnieźnie, Roczniki Historyczne 74, 2008, s. 179-192; E. S k i b i ń s k i, P. S t r ó ż y k, Inskrypcja na średniowiecznej chrzcielnicy w katedrze w Gnieźnie, Studia Epigraficzne 4, 2011, s. 37-41 oraz tabl. na końcu tomu. 
Jeśli zatem herby na chrzcielnicy gnieźnieńskiej odnosiły się do pochodzenia fundatora, a także uwieczniały - jak możemy przyjąć - wybranych członków kapituły, to i pod takim kątem powinniśmy rozpatrzeć herby na obiekcie z katedry w Poznaniu. Przyjmując, że mamy do czynienia z następującymi herbami: Nałęcz, Awdaniec, Łodzia/Połkozic, Leliwa, musimy sprawdzić, czy nie są to herby członków kapituły poznańskiej przed 1447 r. Podobieństwo stylistyczne chrzcielnicy poznańskiej do obiektu z Gniezna, a także kształt namalowanych tarcz herbowych pozwalają zawęzić czasowo obszar naszych poszukiwań do lat trzydziestych i czterdziestych XV w.

Skład kapituły z tego okresu mamy dziś dobrze rozpoznany dzięki pracy Pawła Dembińskiego ${ }^{17}$. Z jego ustaleń wynika, że jedynym kanonikiem herbu Połkozic był w XV w. Jan Rzeszowski, ur. ok. 1468 r., który otrzymał kanonikat w 1488 r. ${ }^{18}$ Jeśli zatem herby z poznańskiej chrzcielnicy miałyby się odnosić do żyjących kanoników, to moglibyśmy trzeci z opisanych znaków identyfikować raczej z Łodzią - pamiętając, że może to być Połkozic, jeżeli mielibyśmy do czynienia z wywodem przodków konkretnej osoby. P. Dembiński nie stwierdził też, aby przed 1447 r. zasiadał w kapitule przedstawiciel rodu Leliwów ${ }^{19}$. W całym badanym przez siebie okresie odnotował on tylko dwóch kanoników tego herbu: Mikołaja Sierpowskiego, prawdopodobnie herbu Leliwa, kanonika od 1467, oraz Wincentego Jurkowskiego, pewnego Leliwitę, który nie objął scholasterii w 1455, a kanonikiem był od 1463 r. Z ustaleń P. Dembińskiego wynika też, że w badanym okresie zasiadało w kapitule siedmiu Awdańców ${ }^{20}$. Wydaje się jednak mało prawdopodobne, ze względu na sekwencję dat, aby herb wymalowany na chrzcielnicy odnosił się do któregoś z nich. Florian z Poklatek był kanonikiem od 1396, a zmarł w 1433 r.; Jan Konarski był kanonikiem od 1499 r.; Jan Skóra z Gaju - od 1446, lecz zmarł już w 1447 r.; recepcja Mikołaja Rogowskiego nastąpiła w 1466 r.; Paweł z Czechowa został kanonikiem w 1404, a zmarł między 1428 a 1429 r., jako archidiakon śremski; w końcu Wojciech Skóra z Gaju został kanonikiem przed 1455, a zmarł w 1487 r.; wreszcie Wojciech Młodszy z Gaju był kanonikiem od 1487 r. Wydaje się więc, że możliwość ukazania herbów należących do członków kapituły należy odrzucić. Tę konstatację wzmacnia też liczba czterech wymalowanych tu znaków, odpowiadająca klasycznym wymogom wywodu przodków.

W XV w. kapituła poznańska zdominowana była przez przedstawicieli rodów pieczętujących się herbem Łodzia i Nałęcz ${ }^{21}$. Wydaje się, że między członkami tych właśnie rodów powinniśmy poszukiwać potencjalnego fundatora chrzcielnicy. W interesującym nas okresie (lata trzydzieste i czterdzieste XV w., przed $1447 \mathrm{r}$.) wskazać możemy następujących przedstawicieli Nałęczów (w tym i takich, których

${ }^{17}$ P. D e m b i ń s ki, Poznańska kapituła katedralna schyłku wieków średnich. Studium prozopograficzne 1428-1500, Poznań 2012.

18 Tamże, s. 471-472 (Jan Rzeszowski).

19 Tamże, s. 144-146, 585-586 (Mikołaj Sierpowski), 688-689 (Wincenty Jurkowski).

20 Tamże, s. 144-145, 382-383 (Florian z Poklatek), 431-432 (Jan Konarski), 472-473 (Jan Skóra z Gaju), 584-585 (Mikołaj Rogowski), 604-607 (Paweł z Czechowa), 705 (Wojciech Młodszy z Gaju), 718-722 (Wojciech Skóra z Gaju).

${ }^{21}$ Tamże, s. 147-148. 
przynależność rodowa nie jest całkowicie pewna) ${ }^{22}$ : Mikołaja Dobiszewskiego (Śremskiego) zw. Kokoszką, kanonika od 1424 r., zmarłego w 1444; Mikołaja Imbira z Objezierza kanonika od 1438; Mikołaja z Soboty kanonika od 1439-1440 r.; Piotra Pniewskiego kanonika przed 1435; Sędziwoja z Soboty kanonika od 1443; Wojciecha Chomęckiego kanonika od 1444. Z kolei z rodu Łodziów wymienić należy ${ }^{23}$ : Andrzeja Rogalińskiego kanonika od 1446; Jakuba Starszego Wygonowskiego archidiakona pszczewskiego od 1417, kanonika od 1433; Jana Głębockiego kanonika od 1445; Jana z Popowa kanonika od 1445; Mikołaja Młodszego Głębockiego kanonika od lat 1440-1442; Mikołaja Starszego Głębockiego kanonika od 1417, zmarłego w 1468; Mikołaja z Górki czynnego w kapitule od końca XIV w., zmarłego w 1439 r.; Mirosława Młodszego z Bytynia kanonika od 1439-1440; Wyszotę z Górki kantora od 1430, a prepozyta od 1432 .

Problem w tym, że wyprowadzenie pełnych wywodów genealogicznych poszczególnych kanoników jest albo niemożliwe z powodu braku wystarczających danych źródłowych, albo wielce niepewne, albo też - jeśli przodkowie kanoników są źródłowo uchwytni - ich przynależność rodowa nie koresponduje z herbami znajdującymi się na chrzcielnicy. Z jednym wszak, ale jakże istotnym, wyjątkiem - wywodu Andrzeja Bnińskiego herbu Łodzia, o którym jeszcze nie wspomnieliśmy. Urodził się ok. 1396-1397, zmarł zaś w 1479 r. ${ }^{24}$ Był synem kasztelana międzyrzeckiego Mikołaja i Małgorzaty. Jako kanonik wystąpił po raz pierwszy w 1435, ale starał się o tę godność już od końca 1431 r. (tocząc spór z Mikołajem Drzewickim). W 1438 r. Andrzej został biskupem poznańskim (sakra 15 II 1439). W poznańskiej katedrze zachowała się jego płyta nagrobna z herbami ukazującymi wywód jego przodków. Widnieją na niej: Łodzia - Nałęcz - Awdaniec - Leliwa ${ }^{25}$. Pozostałości takich samych znaków (z możliwością alternatywnej identyfikacji: Łodzia/Połkozic) widnieją też na poznańskiej chrzcielnicy. Nie bez znaczenia dla naszych dociekań będzie też kolejność herbów na chrzcielnicy, odpowiadająca - przy rzucie z góry - kolejności znaków w herbie złożonym biskupa (fot. 14 i 15) ${ }^{26}$.

22 Tamże, s. 533-534 (Mikołaj Dobiszewski zw. Kokoszka), 547-548 (Mikołaj Imbir z Objezierza), 588-592 (Mikołaj z Soboty), 626-629 (Piotr Pniewski), 642-644 (Sędziwój z Soboty), 704-705 (Wojciech Chomęcki).

23 Tamże, s. 360-361 (Andrzej Rogaliński), 406-408 (Jakub Starszy Wygonowski), 420 (Jan Głębocki), 465-467 (Jan z Popowa), 536-537 (Mikołaj Młodszy Głębocki), 537-542 (Mikołaj Starszy Głębocki), 543-544 (Mikołaj z Górki) 600-602 (Mirosław Młodszy z Bytynia), 725728 (Wyszota z Górki).

${ }^{24} \mathrm{~W}$ literaturze przedmiotu urodziny Andrzeja Bnińskiego datowane są na ok. 1396 (J. N o w a c k i, Bniński Andrzej, w: Polski słownik biograficzny, t. II, Kraków 1936, s. 143; t e n ż e, Dzieje archidiecezji poznańskiej, t. II, Poznań 1964, s. 85) lub na ok. 1397 r. (P. D e m b i ńs k i, Poznańska kapituła, s. 347). Daty urodzin nie podaje J. Krzyża ni a k owa, Bniński Andrzej, w: Wielkopolski słownik biograficzny, Warszawa-Poznań 1981, s. 60-61.

${ }_{25}$ P. Mrozowski, Polskie nagrobki, s. 218-219, il. 97; J. J arzewicz, A. Kar ło w s ka - K a m z ow a, B. Tre li ń s k a, Gotyckie spiżowe płyty nagrobne w Polsce. Studia o formie i treściach ideowych, Poznań 1997, s. 104-106, ryc. XXIX.

${ }^{26}$ Zgodnie $\mathrm{z}$ zasadami heraldyki, przy obrazowaniu wywodu przodków, w przypadku czterech herbów ułożonych w szeregu, można było ukazać tarcze w układzie postępującym: 1-23-4, albo też - rozpoczynając narrację od środka - w układzie: 3-1-2-4. Układ 1-2-3-4 (biorąc za punkt odniesienia kolejność herbów na płycie nagrobnej biskupa Andrzeja Bnińskiego, czyli 
Należy jednak wspomnieć, że wywód przodków biskupa Andrzeja, znany nam z jego płyty nagrobnej, był w literaturze przedmiotu kwestionowany. Małgorzatę z Miłosławia, matkę biskupa, uznawano bowiem za przedstawicielkę Doliwów ${ }^{27}$, ale ostatnio Witold Brzeziński stwierdził, że nie ma ku temu podstaw. Wskazał natomiast, że jako consanguineus biskupa określany był Mikołaj Sobocki z Nałęczów, sugerując, że matka Andrzeja pochodziła z Sobockich ${ }^{28}$. Problem przynależności rodowej matki biskupa nie jest zresztą dla naszych rozważań istotny. Niezależnie od wiarygodności genealogicznej wywodu, kluczowe znaczenie ma dla nas okoliczność, że na chrzcielnicy - jeśli nasze identyfikacje są właściwe (a Leliwa i Łodzia nie są przecież do końca pewne) - widnieje taki sam zespół herbów, jak na płycie nagrobnej, a więc fundację chrzcielnicy można przypisać Andrzejowi z Bnina.

Uznając Andrzeja za fundatora, możemy datować powstanie chrzcielnicy na czas między 1435 (objęcie kanonii) a 1447 r. (pierwsza wzmianka źródłowa o chrzcielnicy), hipotetycznie uściślając to na lata 1439-1447, jeśli uznalibyśmy za bardziej prawdopodobne, że była to już fundacja biskupia. Akt taki doskonale wpisywałby się w znaną nam działalność Andrzeja z Bnina, którego szczodrobliwość, zwłaszcza wobec katedry i licznych kościołów, choć bez wzmianki o ufundowaniu jakiejkolwiek chrzcielnicy, głosi Katalog biskupów poznańskich Jana Długosza: Fabricavit is castrum nobile in Krobya ex coctis lateribus; item ecclesiam Sancte Mariae collegiatam et curiam episcopalem in Posnania; item ecclesiam in oppido Dolsko; item ecclesiam in Kozlow; item ecclesiam in Bnyn; item ecclesiam in Krobya. - -

Łodzia-Nałęcz-Awdaniec-Leliwa) nie wystąpił na chrzcielnicy. Niekiedy w herbach złożonych lub zespołach herbów zamieniano miejscami dwa ostatnie znaki (z czterech przedstawianych), tworząc układ: 1-2-4-3, ale tę możliwość w naszym przypadku należy odrzucić, bowiem kolejność herbów powinna postępować od prawej heraldycznie (dla patrzącego od lewej) ku lewej heraldycznie (dla patrzącego ku prawej), a w naszym przypadku mielibyśmy kolejność odwrotną: 3-4-2-1. Także i drugi możliwy układ (3-1-2-4) nie został zrealizowany na interesującym nas obiekcie, chyba że uznamy, iż zaszło błędne odniesienie do stron heraldycznych: 4-2-1-3, co jednak wydaje się mało prawdopodobne. Taki „naprzemienny” układ znaków byłby zresztą nieczytelny dla odbiorcy okrążającego pokrywę chrzcielnicy. Widać więc, że malarz nie bardzo wiedział, w jakiej kolejności winien prawidłowo rozmieścić poszczególne herby. Jeśli przyjąć, co możliwe, że wykonawca otrzymał jakiś projekt uwzględniający kolejność znaków, to należy skonstatować, że malarz niejako „od góry” powtórzył rozmieszczenie znaków właściwe dla herbu złożonego, wyznaczając im w ten sposób miejsce na pokrywie, co w efekcie - rozpoczynając od herbu Łodzia i „czytając” znaki po kolei, zgodnie z regułami heraldyki - dało układ: 1-3-4-2, czyli: Łodzia-Awdaniec-Leliwa-Nałęcz. O różnych możliwościach „,czytania” herbów złożonych zob. P. S tró ży k, O potrzebie i możliwościach badań nad herbami złożonymi. Uwagi na przykładzie ikonograficznych źródeł heraldycznych z Wielkopolski, w: Ad fontes. O naturze źródła historycznego, Wrocław 2004 (Acta Universitatis Wratislaviensis, Historia CLXX), s. 211.

27 Zob. J. N o w a c k i, Bniński Andrzej, s. 143-145; t e n ż e, Dzieje, t. II, s. 85 (tu przeciwstawny pogląd); W. D w o r z a c z e k, Genealogia, Warszawa 1959, cz. II, tabl. 112; Z. G ó r c z a k, Rozwój majątków możnowładztwa wielkopolskiego w drugiej połowie XV wieku i początkach XVI wieku, Poznań 2007, s. 37; P. D e m b i ń s k i, Poznańska kapituła, s. 347.

${ }^{28}$ W. B r z e z iń s k i, Koligacje Bnińskich herbu Łodzia w późnym średniowieczu, Roczniki Historyczne 73, 2007, s. 188-190; t e n ż e, Koligacje małżeńskie możnowładztwa wielkopolskiego w drugiej połowie XIV wieku i pierwszej połowie XV wieku, Wrocław 2012, s. $72-73$. 
Liberalis itidem in suam Posnaniensem ecclesiam: qui illi duos calices aureos, quinque casulas de axamento auro intexto, cum crucibus latis et amplis, margaritis unionibusque ornatas; item plures casulas ex purpuris variis donavit. Liberalis, et ut verius dicam, prodigus in omnes suae diocesis ecclesias, ea singulari largitione, quam de nullo unquam pontificum, regum et principum legi, refulgens: qui pro anno quolibet, quibus praesidebat, calicem fabricabat argenteum, quo per annum uпит usus, alicui pauperi ecclesiae illum lapso anno donabat, et sic faciebat per singulos annos, quibus gerebat petalum pontificale ${ }^{29}$.

Zaproponowane uściślenie na lata 1439-1447 zbliżałoby czas powstania chrzcielnicy poznańskiej do czasu wykonania analogicznego obiektu z katedry gnieźnieńskiej, ufundowanego, jak głosi inskrypcja, w $1448 \mathrm{r}$. Nie bez znaczenia są tu podobieństwo stylistyczne i technika wykonania oraz zdobienia obydwu obiektów. Mają one podobne wymiary: poznański - wysokość $155 \mathrm{~cm}$ (po późniejszych przeróbkach), średnica $76 \mathrm{~cm}$; gnieźnieński - wysokość $180 \mathrm{~cm}$, średnica $76 \mathrm{~cm}$. Podobna jest też wielkość malowanych tarcz herbowych: w Poznaniu - wysokość 13-14,5 cm, szerokość 12-13 cm; w Gnieźnie - wysokość 13-15 cm, szerokość 11-12,5 cm. Nie wykluczone zatem, że obiekty mogły być wykonane nawet w tym samym warsztacie. Zastanawia jednak brak na poznańskiej chrzcielnicy ikonograficznych odniesień do biskupiej godności Andrzeja z Bnina. Nad herbem Łodzia nie ma żadnych śladów infuły i pastorału biskupiego, zwyczajowo uwidacznianych nad tarczami herbowymi infułatów. Może było to spowodowane tylko brakiem miejsca na owe oznaki godnościowe, tuż nad tarczami herbowymi osadzony został bowiem wycięty w metalu fryz, dookolnie zdobiący pokrywę chrzcielnicy. Pamiętać jednak musimy, że herby umieszczone są jedynie w czterech $\mathrm{z}$ ośmiu pól pokrywy, a więc istniała - przynajmniej potencjalnie - możliwość właściwego zamanifestowania biskupiego statusu w ramach wolnych pól, ale te wypełniono tylko motywami florystycznymi. Nie możemy wykluczyć, że - podobnie jak na obiekcie z Gniezna - na czaszy poznańskiej chrzcielnicy umieszczono pierwotnie inskrypcję, po której nie ma dziś śladu, wspominającą także biskupią godność Andrzeja z Bnina. To thumaczyłoby brak odniesień w zespole namalowanych herbów. Podobnie bowiem rozwiązano tę kwestię na nagrobku biskupa Andrzeja ${ }^{30}$. Heraldyczny wywód przodków hierarchy pojawił się tam dwukrotnie. Na bordiurze inskrypcyjnej umieszczono, osobno, cztery herby wkomponowane $\mathrm{w}$ czterolistne medaliony, na parurze zaś biskupiej alby umieszczono tarczę czterodzielną w krzyż, na której powtórzono ten sam zestaw herbów. W warstwie heraldycznej brak jakichkolwiek odniesień do godności biskupiej.

Chrzcielnice z Poznania i Gniezna musiały powstać w zbliżonym czasie, jednak położenie herbów i w pewnym zakresie ich treść są inne. Być może różne położenie herbów nie jest przypadkowe, wobec kolejności powstawania tych obiektów. Jeśli chrzcielnica poznańska, z herbami umieszczonymi na jej pokrywie, była - jak przypuszczamy - fundacją już biskupią, to może zamawiając chrzcielnicę gnieźnieńską, naśladującą poznańską, świadomie nie zdecydowano się na podobne, ostentacyjne

${ }^{29}$ Joannis Dlugossii, Opera omnia, wyd. A. Przezdziecki, t. I, Kraków 1887, s. 511-512. Zob. także J. N ow a c k i, Bniński Andrzej, s. 144.

${ }^{30}$ P. Mrozowski, Polskie nagrobki, s. 218-219, il. 97; J. Jarzewicz, A. Karłow s k a-K a m z ow a, B. Tre liń s k a, Gotyckie spiżowe płyty, s. 104-106, ryc. XXIX. 
umieszczenie herbów na pokrywie, decydując się na rozmieszczenie ich w miejscu, w jakim umieszczano je na chrzcielnicach kamiennych, fundowanych zwykle przez rycerstwo ${ }^{31}$.

Podsumowując powyższe rozważania, należy przyjąć, że malowane, barwne herby, fragmentarycznie zachowane na metalowej chrzcielnicy z katedry w Poznaniu, to $\mathrm{z}$ dużym prawdopodobieństwem: Łodzia - Nałęcz - Awdaniec - Leliwa (choć pierwszy i ostatni z wymienionych znaków są bardzo słabo zachowane). Oddają one najprawdopodobniej wywód przodków biskupa poznańskiego Andrzeja z Bnina. Chrzcielnica poznańska jest starsza od gnieźnieńskiej, ufundowanej w 1448 r., a powstała między 1435 (kiedy Andrzej został kanonikiem poznańskim) a $1447 \mathrm{r}$. (z którego pochodzi najstarsza znana nam wzmianka o niej). Czas ten można ostrożnie uściślić na lata 1439-1447, uznając za bardziej prawdopodobne ufundowanie obiektu przez Andrzeja z Bnina już po objęciu przez niego godności biskupa poznańskiego.

\section{BIBLIOGRAFIA}

Brzeziński W., Koligacje Bnińskich herbu Łodzia w późnym średniowieczu, Roczniki Historyczne 73, 2007.

Brzeziński W., Koligacje małżeńskie możnowładztwa wielkopolskiego w drugiej połowie XIV wieku i pierwszej połowie XV wieku, Wrocław 2012.

Dembiński P., Poznańska kapituła katedralna schyłku wieków średnich. Studium prozopograficzne 1428-1500, Poznań 2012.

Dworzaczek W., Genealogia, Warszawa 1959.

Górczak Z., Rozwój majątków możnowładztwa wielkopolskiego w drugiej połowie XV wieku i początkach XVI wieku, Poznań 2007.

Jarzewicz J., Karłowska-Kamzowa A., Trelińska B., Gotyckie spiżowe płyty nagrobne w Polsce. Studia o formie i treściach ideowych, Poznań 1997.

Katalog zabytków sztuki w Polsce, seria nowa, t. VII, cz. 1, red. E. Linette, Z. Kurzawa Warszawa 1983.

Kohte J., Die Kunstdenkmäler des Stadtkreises Posen (Verzeichnis der Kunstdenkmäler der Provinz Posen, t. II), Berlin 1896.

Krzyżaniakowa J., Bniński Andrzej, w: Wielkopolski słownik biograficzny, Warszawa-Poznań 1981.

Kuczyńska J., Średniowieczne chrzcielnice kamienne w Polsce, Katalog, Lublin 1984.

Mrozowski P., O sztuce i stylizacji heraldycznej w Polsce XIV-XV wieku, Rocznik Polskiego Towarzystwa Heraldycznego, nowa seria 1 (12), 1993.

Mrozowski P., Polskie nagrobki gotyckie, Warszawa 1994.

Nawrocki S., Przewodnik po katedrze poznańskiej, Poznań 1930.

Nowacki J., Bniński Andrzej, w: Polski słownik biograficzny, t. II, Kraków 1936.

Nowacki J., Dzieje archidiecezji poznańskiej, t. I-II, Poznań 1959-1964.

Paluszkiewicz M., Katedra poznańska i jej zabytki, Poznań 1938.

Piekosiński F., Heraldyka polska wieków średnich, Kraków 1899.

Skibiński E., Stróżyk P., Inskrypcja na średniowiecznej chrzcielnicy w katedrze w Gnieźnie, Studia Epigraficzne 4, 2011.

Stróżyk P., Barwne herby na średniowiecznej chrzcielnicy z katedry w Gnieźnie, Roczniki Historyczne 74, 2008.

${ }^{31}$ Zob. J. K u c z y ń s k a, Średniowieczne chrzcielnice kamienne w Polsce, Katalog, Lublin 1984; zob. także rec. J. S z y m a ń s k i e g o, Studia Źródłoznawcze 32-33, 1990, s. 238-240. 
Stróżyk P., O potrzebie i możliwościach badań nad herbami złożonymi. Uwagi na przykładzie ikonograficznych źródeł heraldycznych z Wielkopolski, w: Ad fontes. O naturze źródła historycznego, Wrocław 2004 (Acta Universitatis Wratislaviensis, Historia CLXX).

Szymański J., Herbarz średniowiecznego rycerstwa polskiego, Warszawa 1993.

Szymański J., rec. z pracy J. Kuczyńskiej, Średniowieczne chrzcielnice kamienne w Polsce, Studia Źródłoznawcze 32-33, 1990.

Śliwiński B., Zagadkowy herb z kościoła w Bolechowicach koło Krakowa, Rocznik Polskiego Towarzystwa Heraldycznego, nowa seria 2 (13), 1995.

\title{
Die Wappen auf dem Taufbecken der Domkirche zu Posen
}

\section{Zusammenfassung}

In der Posener Domkirche St. Peter und Paul hat sich ein gotisches Taufbecken aus Metall erhalten, auf dem im Frühjahr 2016 Polychromiereste mit fragmentarisch erhaltenen vier Wappen entdeckt wurden. Die auf uns gekommenen archivalischen Erwähnungen lassen die Entstehung des Objekts auf die Zeit vor dem 30. April 1447 datieren. Auf dem Deckel des Taufbeckens sind höchstwahrscheinlich die Wappen folgender Geschlechter zu sehen: Łodzia - Nałęcz Awdaniec - Leliwa (das erste und das letzte Wappen sind sehr schlecht erhalten, weshalb ihre Identifizierung nur hypothetisch ist). Die Wappen stellen die Ahnenprobe des Posener Bischofs Andreas von Bnin (um 1396/1397-1479) dar, die bereits von seiner Bronzegrabplatte aus dem Posener Dom bekannt ist. Das Posener Taufbecken ist älter als das Gnesener, das 1448 gestiftet wurde. Es entstand zwischen 1435 (als Andreas Posener Domherr wurde) und 1447 (als das Taufbecken zuerst erwähnt wird). Seine Entstehung kann vorsichtig auf die Jahre 1439-1447 eingegrenzt werden, da es wohl wahrscheinlicher ist, das Andreas von Bnin das Objekt erst nach der Übernahme des Bistums Posen gestiftet hat.

Übersetzt von Waldemar Könighaus

\section{Coats-of-arms on the gothic baptismal font in the Poznań Cathedral}

\author{
Abstract
}

In the Poznań Cathdral of St. Apostles Peter and Paul there is a gothic metal baptismal font, on which remains of colour polychromy with fragments of four coats-of-arms were found in the spring of 2016. Some written sources allow to date the object to before 30 April 1447. On its cover there are most probably the arms of the knightly clans: Łodzia - Nałęcz - Awdaniec Leliwa (the first and last of these are hardly visible so their identification is only hypothetical). The coats-of-arms display the ancestry of Andrzej of Bnin, bishop of Poznan, of the Lodzia clan (b. circa 1396/1397, d. 1479), known also from his bronze tomb slate, preserved in the Poznań Cathedral. The Poznań font is older than that of Gniezno, produced in 1448. It was made between 1435 (when Andrzej became a canon of Poznań) and 1447 (when it was first mentioned in sources). The dating may be cautiously narrowed to the years 1439-1447, as the object was most probably ordered by Andrzej of Bnin after he became the bishop of Poznań.

Translated by Rafat T. Prinke

dr hab. Paweł Stróżyk, Instytut Historii, Uniwersytet im. Adama Mickiewicza, ul. Umultowska 89d, 61-614 Poznań, e-mail: paszeko@amu.edu.pl 


\section{TABLICA I}
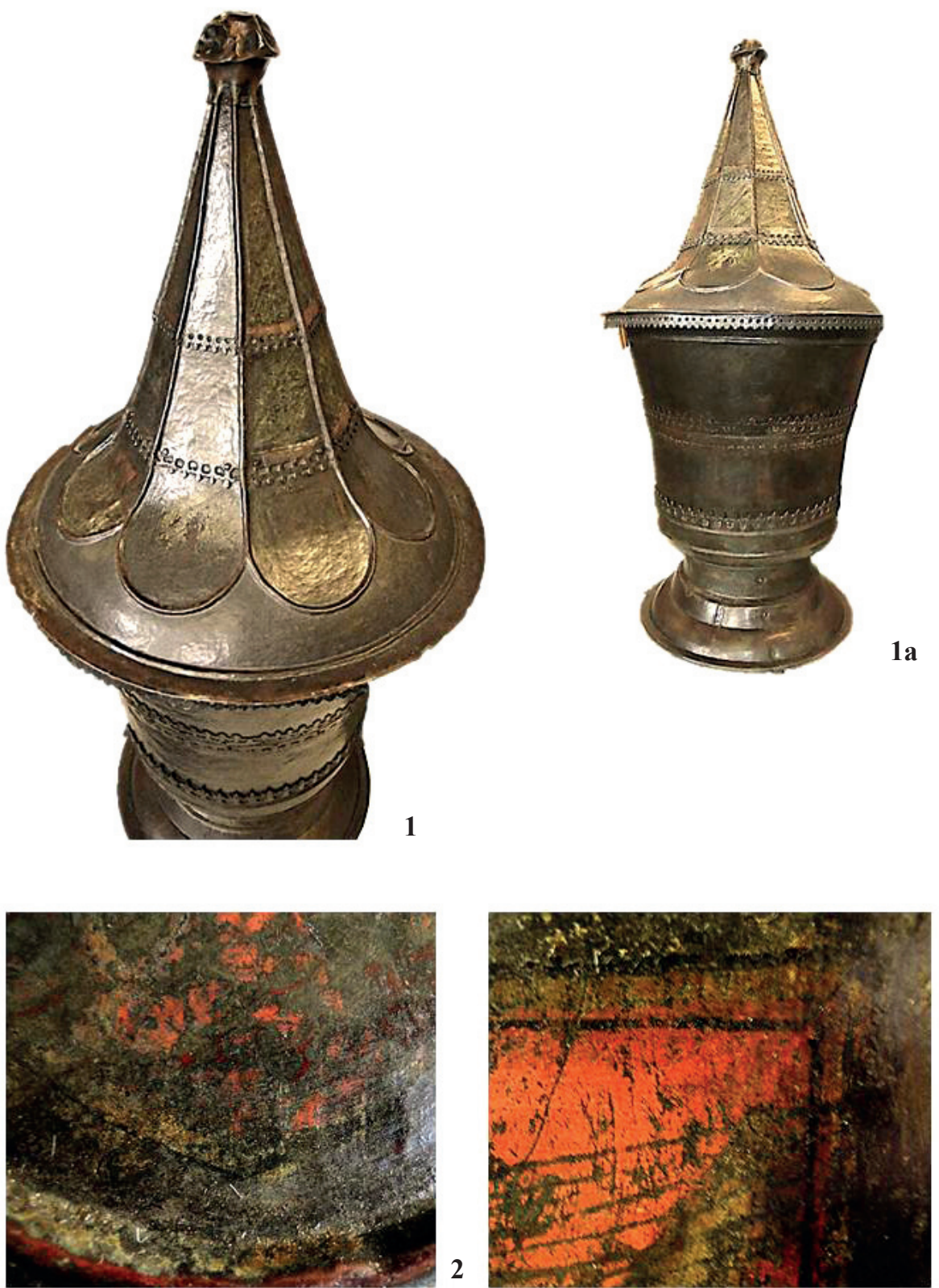

1-1a. Widok ogólny na metalową chrzcielnicę w katedrze w Poznaniu.

2. Linia ostrołukowego zamknięcia podstawy tarczy herbowej (tarcza z herbem Awdaniec).

3. Bordiura tarczy herbowej wyznaczona dwiema czarnymi liniami (tarcza $\mathrm{z}$ herbem Łodzia [?] lub Połkozic [?]). 
TABLICA II
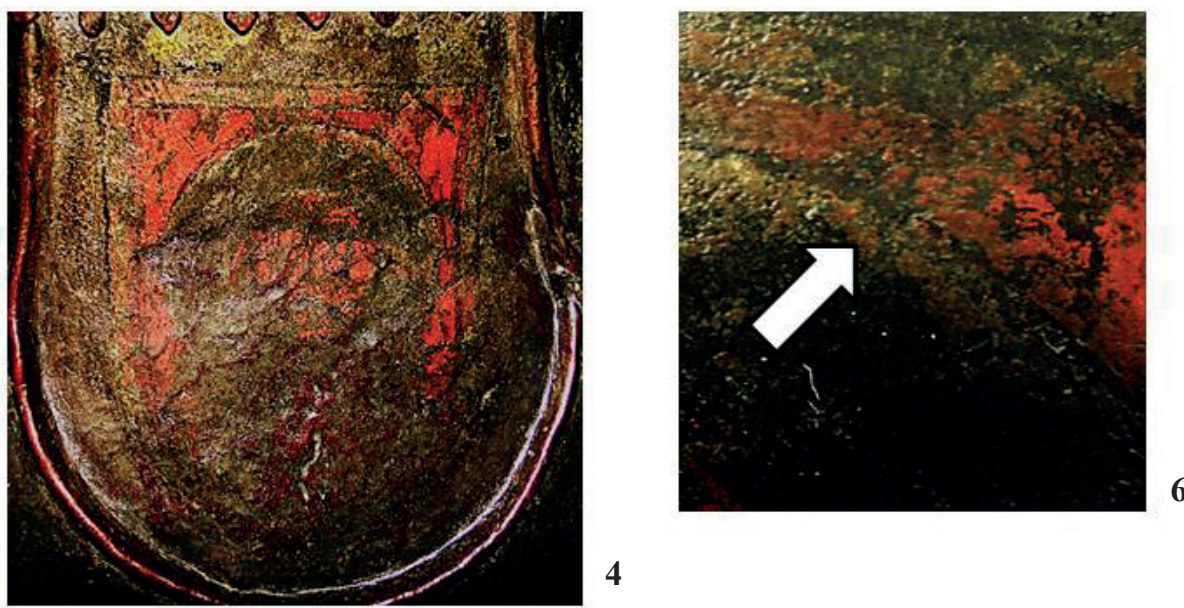

4
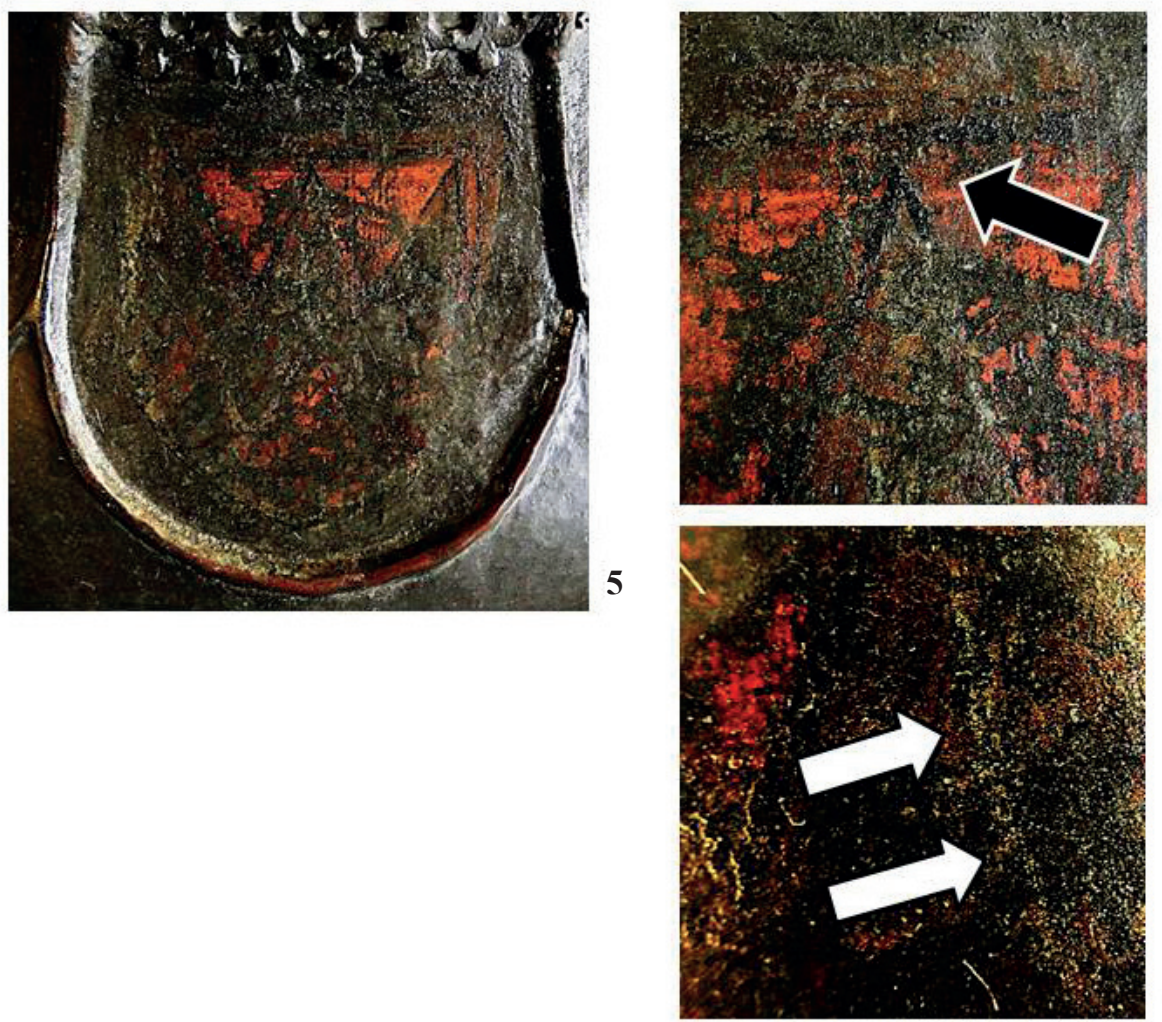

8

4. Tarcza z herbem Nałęcz.

5. Widoczne pozostałości białej (heraldycznie: srebrnej) barwy godła w herbie Nałęcz.

6. Tarcza $\mathrm{z}$ herbem Awdaniec.

7. Ukośne linie górnej, środkowej części godła z herbu Awdaniec oraz pozioma linia tarczy herbowej, od głowicy.

8. Pozostałość białej (heraldycznie: srebrnej) barwy godła w herbie Awdaniec. 


\section{TABLICA III}

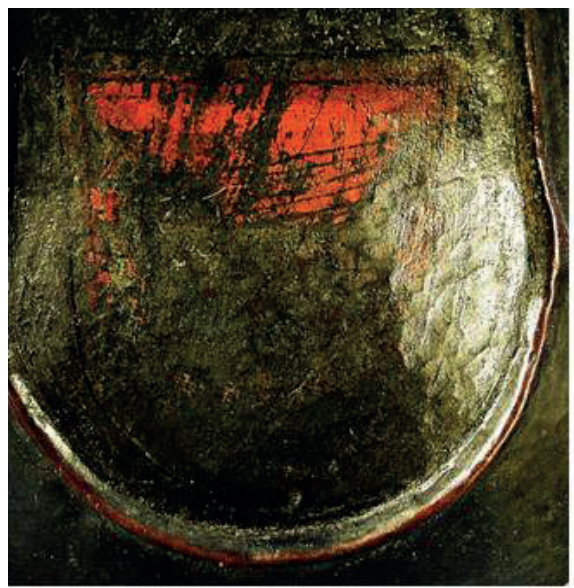

9
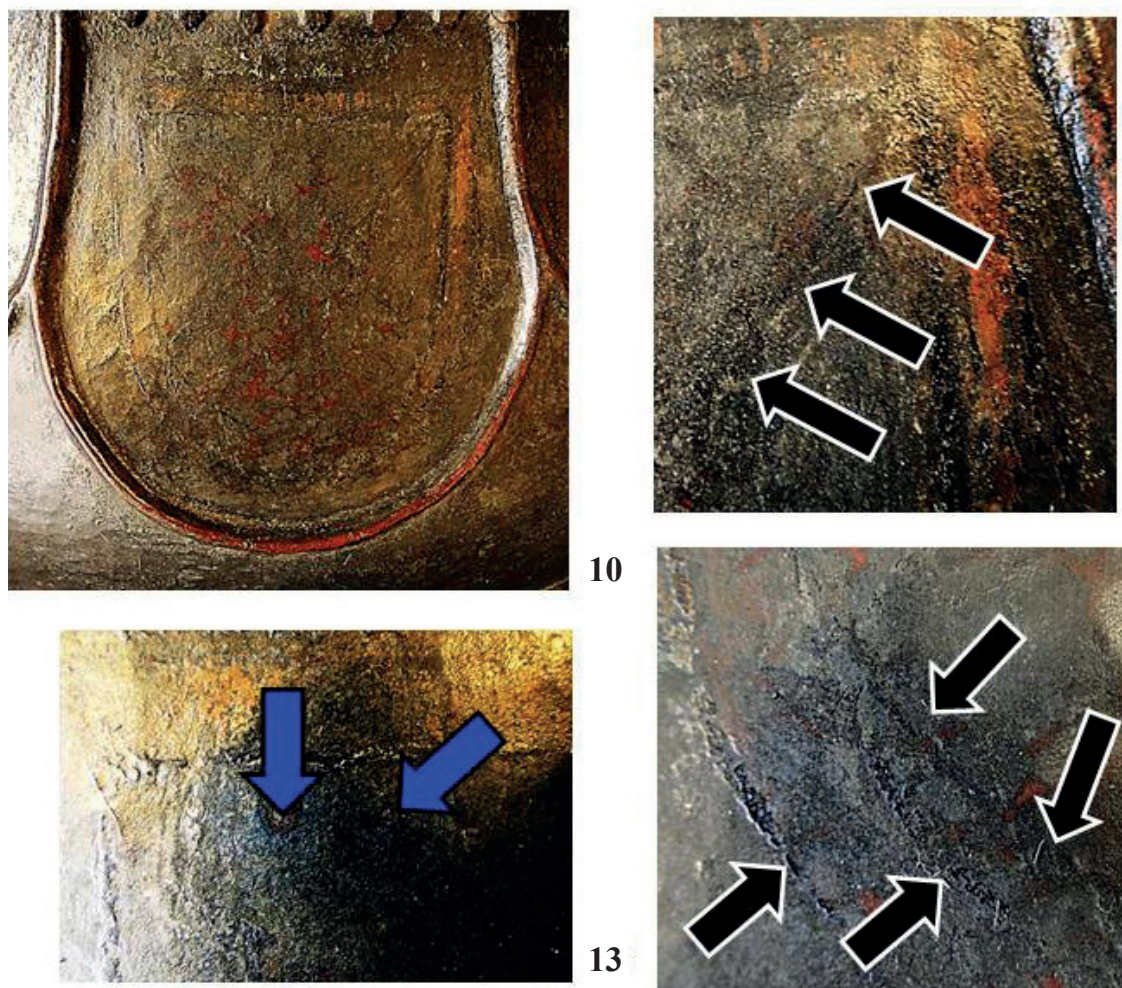

10

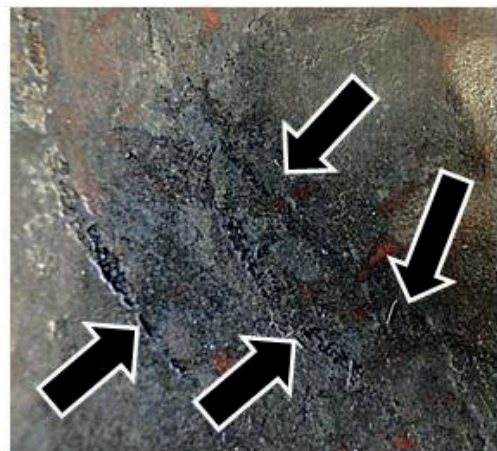

9. Tarcza z herbem Łodzia (?) lub Połkozic (?).

10. Tarcza $z$ herbem Leliwa (?).

11. Ukośna linia elementu godła, biegnąca ku heraldycznie lewemu, górnemu narożnikowi tarczy herbu Leliwa (?).

12. Łukowate, równoległe linie tarczy herbowej wraz z bordiurą oraz łukowata linia elementu godła herbowego, widoczne w heraldycznie prawej części podstawy tarczy z herbem Leliwa (?). 13. Pozostałość błękitnej barwy godła w herbie Leliwa (?). 
TABLICA IV
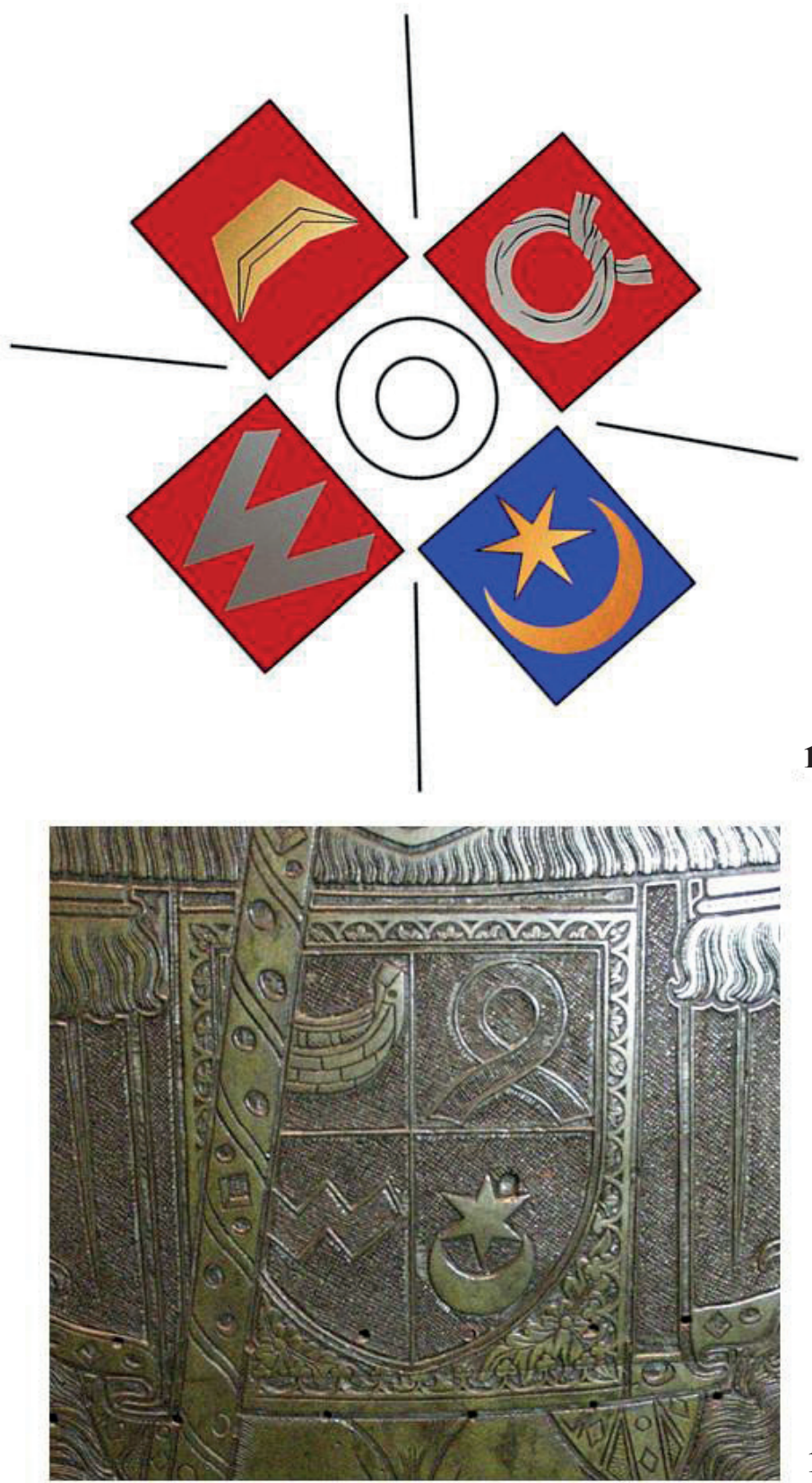

15

14. Graficzny schemat rozmieszczenia herbów na pokrywie chrzcielnicy z katedry w Poznaniu (rzut z góry), przy wariantywnym uwzględnieniu herbu Łodzia (?).

15. Herb złożony biskupa Andrzeja z Bnina na jego płycie nagrobnej, katedra w Poznaniu.

Fot. i ryc. P. Stróżyk 